\title{
Hemodynamic Effects of Intravenous Prenalterol in Severe Heart Failure
}

PHILIP C. KIRLIN, MD*

BERTRAM PITT, MD, FACC

Ann Arbor, Michigan
From the Division of Cardiology, Department of Internal Medicine, University of Michigan Medical Center, Ann Arbor, Michigan. Manuscript received July 24, 1980; revised manuscript received October 6, 1980, accepted October 9, 1980.

- Research Fellow, Michigan Heart Association. Southfield, Michigan.

Address for reprints: Bertram Pitt, MD, Division of Cardiology, Department of Internal Medicine, University of Michigan Medical Center, Ann Arbor, Michigan 48109.
Nine patients with chronic severe low output heart failure (radionuclide left ventricular ejection fraction $17 \pm 5$ percent [mean \pm standard deviation], left ventricular fllling pressure $26 \pm 6 \mathrm{~mm} \mathrm{Hg}$, cardiac index 1.9 \pm 0.4 liters $/ \mathrm{min}$ per $\mathrm{m}^{2}$, left ventricular stroke work index $18 \pm 6 \mathrm{~g}-\mathrm{m} / \mathrm{m}^{2}$ ) from various causes were treated with intravenous prenalterol (a new catecholamine-like inotropic agent) in doses of 1, 4 and $8 \mathrm{mg}$. Significant hemodynamic improvement occurred as measured by increased left ventricular ejection fraction (to $26 \pm 4$ percent), decreased left ventricular filling pressure (to $21 \pm 8 \mathrm{~mm} \mathrm{Hg}$ ) and increased cardiac index (to 2.4 \pm 0.6 liters $/ \mathrm{min}$ per $\mathrm{m}^{2}$ ) and left ventricular stroke work index (to $25 \pm$ $8 \mathrm{~g}-\mathrm{m} / \mathrm{m}^{2}$ ). Significant increases in heart rate (from $87 \pm 18$ to $91 \pm 18$ beats/min) and mean systemic arterial pressure (from $87 \pm 8$ to $92 \pm 7$ $\mathrm{mm} \mathrm{Hg}$ ) also occurred. Peak hemodynamic response occurred at various doses. Significant adverse effects associated with prenalterol consisted of increased ventricular ectopic beats in two patients and asymptomatic ventricular tachycardia in two patients. Thus, intravenous prenalterol produces hemodynamic improvement in patients with a chronic severe low output state but may be associated with increased ventricular ectopic activity.

Prenalterol (levorotatory form of 1-isopropylamino-3-[p-hydroxyphenoxy]-2-propanol hydrochloride) is a new catecholamine-like cardiac inotropic agent which has been shown in animal ${ }^{1,2}$ and human ${ }^{3-9}$ studies $^{-1}$ to possess relatively selective beta ${ }_{1}$ adrenergic stimulating properties, resulting in a positive inotropic response with acceptable chronotropic and vasoactive properties. Because it is effective both orally and parenterally, it has been proposed for use in the therapy of both acute and chronic heart failure, including potential use as an adjunct or substitute for cardiac glycoside therapy in selected patients. The current study was undertaken to provide an evaluation of the hemodynamic effects of intravenously administered prenalterol in patients with severe low output heart failure.

\section{Methods}

Study patients: Nine patients (mean age $59 \pm 7$ years) with chronic severe symptomatic heart failure (New York Heart Association ${ }^{10}$ functional class II to IV; left ventricular filling pressure, determined from mean pulmonary arterial wedge pressure, greater than or equal to $16 \mathrm{~mm} \mathrm{Hg}$; and left ventricular ejection fraction less than or equal to 30 percent) were included. Seven of the nine patients were in the cardiac intensive care unit for management of heart failure at the time of investigation. Six patients had ischemic heart disease, two had idiopathic failure and one had alcoholic cardiomyopathy. The clinical diagnosis of severe left ventricular dysfunction was substantiated by cardiac catheterization with selective coronary angiography in seven patients, and in the remaining two patients it was supported by $M$ mode echocardiography.

Before study, a complete history was obtained and physical examination was performed with emphasis placed on New York Heart Association functional class and signs of heart failure. Five patients were chronically digitalized with oral 
digoxin at the time of investigation in doses ranging from 0.125 to $0.25 \mathrm{mg}$ daily. Serum digoxin levels in digitalized patients obtained within 1 to 6 days of prenalterol administration ranged from 0.26 to $1.05 \mathrm{mg} / \mathrm{ml}$ (mean 0.74 ). No patient had clinical evidence of digitalis toxicity. All patients required chronic diuretic therapy. Prior antiarrhythmic therapy in two patients (disopyramide, $100 \mathrm{mg}$ orally four times daily, in Patient 8 and quinidinc sulfate, $200 \mathrm{mg}$ orally four times daily, in Patient 9), was continued throughout the study. Vasodilators were withheld for 24 hours. Digitalis and diuretic agents were administered at least 6 hours before and antiarrhythmic medications were withheld during administration of the investigational agent. Patients with unstable angina, acute myocardial infarction within 3 months or hypertrophic cardiomyopathy were excluded. The investigative protocol was approved by the Human Use Committee of the University of Michigan Medical Center, and written informed consent was obtained from each patient before study.

Hemodynamic measurements: All patients were studied in the postabsorptive state after placement of a flow-directed pulmonary arterial thermodilution catheter. Systemic arterial pressure was monitored by radial or brachial arterial catheter (seven patients) or sphygmomanometer (two patients). Heart rate was determined from the electrocardiogram. Other hemodynamic variables were determined as follows: Cardiac output was determined in eight patients by thermodilution technique ( 10 cc of iced 5 percent dextrose in water injected by pneumatic pump) and in one patient by indocyanine green using a Lexington cardiac output computer. The mean of triplicate thermodilution or duplicate green dye values was determined at each interval. Pulmonary arterial systolic and diastolic pressures and mean pulmonary arterial, mean pulmonary arterial wedge and mean right atrial pressures were obtained directly from the flotation catheter connected to Statham P23DB pressure transducers recorded on an Electronics for Medicine VR12 recorder. Derived hemodynamic variables were obtained from standard formulas. Left ventricular filling pressure was determined from mean pulmonary arterial wedge pressure.

Radionuclide studies: Left ventricular ejection fraction was determined by equilibrium radionuclide gated cardiac blood pool imaging using 10 to $20 \mathrm{mCi}$ of technetium-99m for in vivo labeling of circulating red blood cells. A gamma camera oriented in the modified left anterior oblique position was used for cardiac blood pool imaging. Technically satisfactory radionuclide studies were obtained in eight of the nine patients.

Other laboratory studies: Continuous 24 hour electrocardiographir (Holter) monitoring was obtained on the day of the study for arrhythmia analysis. A minimum of 8 hours of electrocardiographic monitoring was recorded before administration of the investigational drug. Chest roentgenography, 12 lead electrocardiography, complete blood count, platelet count, reticulocyte count, prothrombin time, partial thromboplastin time, urine analysis and determination of SMA 12 blood chemistry values, electrolytes and cardiac enzymes (creatine kinase with isoenzyme pattern, lactic dehydrogenase with isoenzyme pattern and serum glutamic oxaloacetic transaminase analysis) wcre performed before ad ministration of prenaiterol. Analysis of all laboratory data except the chest roentgenogram was repeated after drug administration and compared with pretreatment values.

Prenalterol administration: After two control measurements in the resting state, intravenous prenalterol was administered through a peripheral intravenous line in doses of 1,4 and $8 \mathrm{mg}$ at 30 minute intervals. Each dose was given over 5 minutes by infusion pump, and hemodynamic measure- ments were performed over 5 minutes beginning 10 and 25 minutes after 1 and $4 \mathrm{mg}$ doses and 10,25 and 55 minutes after $8 \mathrm{mg}$ doses. The mean of two baseline control values was used for comparison with values after drug administration.

Statistical analysis: All values were expressed as mean \pm standard deviation. Statistical analysis was performed using the paired $t$ test. A probability ( $p$ ) value of less than or equal to 0.05 was considered statistically significant.

\section{Results}

Severe chronic impairment of left ventricular function was present in all patients. Eight of the nine patients had had symptoms of heart failure for at least 1 year and one patient had had such symptoms for 4 months. Six patients were in New York Heart Association functional class IV, two were in class III and one patient was in class II. Eight of the nine patients had a left ventricular third heart sound $\left(S_{3}\right)$ at the time of study, and seven had received venous or arterial vasodilator therapy for refractory heart failure.

Hemodynamic effects of prenalterol: Hemodynamic data revealed significant improvement in cardiac index and left ventricular stroke work index and ejection fraction associated with a decrease in left ventricular filling pressure (Table I, Fig. 1). Statistically significant increases in systemic and mean arterial pressures and heart rate occurred as well. Diastolic arterial pressure and systemic arteriolar resistance did not change significantly. Pulmonary vascular resistance and mean right atrial pressure decreased significantly. Increases in right ventricular stroke work index were nearly statistically significant $(p<0.06$ ). No significant differences were noted among the three doses, and the peak hemodynamic effect occurred variably after the 1,4 or $8 \mathrm{mg}$ doses.

Effect on ventricular arrhythmia: No adverse hemodynamic effects were noted except for a transient asymptomatic decrease in ejection fraction, cardiac index and stroke work index in Patient 4. Electrocardiographic monitoring revealed ectopic ventricular complexes during the control period in all patients. During subsequent drug administration, two patients had an increased number of ventricular ectopic complexes, and transient unsustained asymptomatic ventricular tachycardia developed in two patients. Patient 5 had had frequent three beat ventricular tachycardia before drug administration and a prolonged ( 172 beat) run of ventricular tachycardia after drug administration. Prenalterol administration was discontinued in this patient and no further ventricular tachycardia was noted on subsequent 24 hour monitoring. Patient 7 manifested a nine beat ventricular tachycardia after drug administration without previous or subsequent ventricular tachycardia. Both Patients 5 and 7 received concomitant digoxin therapy at the time of study. Prenalterol therapy was discontinued in Patient 6 after administration of $4 \mathrm{mg}$ because the number of ventricular ectopic complexes increased.

Adverse effects: All patients tolerated prenalterol administration without subjective complaints of angina pectoris, palpitations, worsening shortness of breath or other symptoms. No electrocardiographic signs of in- 
creased ischemia were noted during drug administration. Fvaluation of laboratory values after drug administration revealed no adverse effects on hematologic, hepatic or cardiac variables, including cardiac enzyme analysis.

\section{Discussion}

Recent advances in the medical management of low output heart failure include the introduction of vasodilator therapy for ventricular preload and afterload reduction as well as the introduction of the potent new parenteral inotropic agents dopamine and dobutamine. However, the only oral inotropic agents currently available for clinical use are the cardiac glycosides, which are associated with a significant incidence of toxicity, including life-threatening cardiac arrhythmias. ${ }^{11}$ Digitalis cardiac toxicity may be enhanced by the frequent concurrent administration of potassiumdepleting diuretic drugs and quinidine, which significantly increases serum digoxin levels and thereby may increase myocardial glycoside concentration to toxic levels. ${ }^{12}$ In addition, several investigators have suggested that chronic cardiac glycoside therapy may be ineffective in some patients with heart failure, as evidenced by a return to pretreatment hemudynamic status upon withdrawal of chronic digitalis therapy. ${ }^{13-16}$

TABLE ।

Characteristics of Patients and Response to Prenalterol

\begin{tabular}{|c|c|c|c|c|c|c|c|c|c|c|c|}
\hline & \multicolumn{9}{|c|}{ Patients } & \multirow[b]{2}{*}{ Mean $\pm \mathrm{SD}$} & \multirow{2}{*}{$\begin{array}{c}\mathrm{p} \\
\text { Versus } \\
\text { Baseline }\end{array}$} \\
\hline & 1 & 2 & 3 & 4 & $5^{*}$ & 6 & 7 & 8 & 9 & & \\
\hline $\begin{array}{l}\text { Age (yr) \& sex } \\
\text { Cause of } \\
\quad \text { cardiomyopathy } \\
\text { Heart rate (beats/min) }\end{array}$ & $\begin{array}{l}63 \mathrm{M} \\
\text { Isch- } \\
\text { emic }\end{array}$ & $\begin{array}{l}53 F \\
\text { Alco- } \\
\text { holic }\end{array}$ & $\begin{array}{l}64 F \\
\text { Isch- } \\
\text { emic }\end{array}$ & $\begin{array}{r}56 F \\
\text { Idio- } \\
\text { pathic }\end{array}$ & $\begin{array}{l}\text { 60F } \\
\text { Isch- } \\
\text { emic }\end{array}$ & $\begin{array}{l}\text { 48M } \\
\text { Idio- } \\
\text { pathic }\end{array}$ & $\begin{array}{l}64 \mathrm{M} \\
\text { Isch- } \\
\text { emic }\end{array}$ & $\begin{array}{l}55 \mathrm{M} \\
\text { Isch- } \\
\text { emic }\end{array}$ & $\begin{array}{l}70 \mathrm{M} \\
\text { Isch- } \\
\text { emic }\end{array}$ & $\begin{array}{c}59 \pm 7 \\
\ldots\end{array}$ & $\cdots$ \\
\hline $\begin{array}{l}\text { Baseline } \\
\text { Maximal } \\
\text { Systolic arterial } \\
\text { pressure } \\
(\mathrm{mm} \mathrm{Hg})\end{array}$ & $\begin{array}{l}75 \\
80\end{array}$ & $\begin{array}{l}74 \\
83\end{array}$ & $\begin{array}{r}89 \\
106\end{array}$ & $\begin{array}{l}120 \\
122\end{array}$ & $\begin{array}{c}110 \\
\ldots\end{array}$ & $\begin{array}{l}71 \\
90\end{array}$ & $\begin{array}{r}96 \\
102\end{array}$ & $\begin{array}{l}75 \\
75\end{array}$ & $\begin{array}{l}72 \\
68\end{array}$ & $\begin{array}{l}87 \pm 18 \\
91 \pm 18\end{array}$ & $<0.05$ \\
\hline $\begin{array}{l}\text { Baseline } \\
\text { Maximal } \\
\text { Mean arterial pressure } \\
(\mathrm{mm} \mathrm{Hg})\end{array}$ & $\begin{array}{l}116 \\
120\end{array}$ & $\begin{array}{l}110 \\
130\end{array}$ & $\begin{array}{l}135 \\
140\end{array}$ & $\begin{array}{l}118 \\
130\end{array}$ & $\begin{array}{c}102 \\
\ldots\end{array}$ & $\begin{array}{l}128 \\
135\end{array}$ & $\begin{array}{l}135 \\
140\end{array}$ & $\begin{array}{l}108 \\
120\end{array}$ & $\begin{array}{l}104 \\
107\end{array}$ & $\begin{array}{l}117 \pm 13 \\
128 \pm 11\end{array}$ & $<0.004$ \\
\hline $\begin{array}{l}\text { Baseline } \\
\text { Maximal } \\
\text { Diastolic arterial } \\
\text { pressure } \\
(\mathrm{mm} \mathrm{Hg})\end{array}$ & $\begin{array}{l}90 \\
92\end{array}$ & $\begin{array}{l}94 \\
98\end{array}$ & $\begin{array}{l}84 \\
91\end{array}$ & $\begin{array}{l}87 \\
98\end{array}$ & $\begin{array}{c}74 \\
\ldots\end{array}$ & $\begin{array}{l}92 \\
93\end{array}$ & $\begin{array}{r}97 \\
100\end{array}$ & $\begin{array}{l}88 \\
94\end{array}$ & $\begin{array}{l}74 \\
77\end{array}$ & $\begin{array}{l}87 \pm 8 \\
92 \pm 7\end{array}$ & $<0.007$ \\
\hline $\begin{array}{l}\text { Baseline } \\
\text { Maximal } \\
\text { LVEF }(\%)\end{array}$ & $\begin{array}{l}78 \\
78\end{array}$ & $\begin{array}{l}86 \\
88\end{array}$ & $\begin{array}{l}62 \\
67\end{array}$ & $\begin{array}{l}71 \\
85\end{array}$ & 62 & $\begin{array}{l}78 \\
75\end{array}$ & $\begin{array}{l}78 \\
82\end{array}$ & $\begin{array}{l}75 \\
76\end{array}$ & $\begin{array}{l}60 \\
65\end{array}$ & $\begin{array}{l}72 \pm 9 \\
77 \pm 8\end{array}$ & $<0.09$ \\
\hline $\begin{array}{l}\text { Baseline } \\
\text { Maximal } \\
\text { LVSWI }\left(\mathrm{g}-\mathrm{m} / \mathrm{m}^{2}\right)\end{array}$ & $\begin{array}{l}17 \\
26\end{array}$ & $\begin{array}{l}t \\
t\end{array}$ & $\begin{array}{l}26 \\
31\end{array}$ & $\begin{array}{l}20 \\
21\end{array}$ & $\begin{array}{r}12 \\
\ldots\end{array}$ & $\begin{array}{l}18 \\
29\end{array}$ & $\begin{array}{l}17 \\
25\end{array}$ & $\begin{array}{l}10 \\
21\end{array}$ & $\begin{array}{l}12 \\
26\end{array}$ & $\begin{array}{l}17 \pm 5 \\
26 \pm 4\end{array}$ & $<0.002$ \\
\hline $\begin{array}{c}\text { Baseline } \\
\text { Maximal } \\
\text { Cardiac Index (liters/min } \\
\text { per } \mathrm{m}^{2} \text { ) }\end{array}$ & $\begin{array}{l}21 \\
28\end{array}$ & $\begin{array}{l}22 \\
21\end{array}$ & $\begin{array}{l}28 \\
30\end{array}$ & $\begin{array}{l}12 \\
17\end{array}$ & $\begin{array}{c}12 \\
\ldots\end{array}$ & $\begin{array}{l}27 \\
40\end{array}$ & $\begin{array}{l}16 \\
22\end{array}$ & $\begin{array}{l}17 \\
28\end{array}$ & $\begin{array}{l}12 \\
15\end{array}$ & $\begin{array}{l}18 \pm 6 \\
25 \pm 8\end{array}$ & $<0.008$ \\
\hline $\begin{array}{l}\text { Baseline } \\
\text { Maximal } \\
\text { LVFP }(\mathrm{mm} \mathrm{Hg})\end{array}$ & $\begin{array}{l}1.9 \\
2.7\end{array}$ & $\begin{array}{l}1.8 \\
1.8\end{array}$ & $\begin{array}{l}2.7 \\
3.1\end{array}$ & $\begin{array}{l}1.8 \\
1.9\end{array}$ & $\begin{array}{l}2.0 \\
\cdots\end{array}$ & $\begin{array}{l}2.0 \\
3.2\end{array}$ & $\begin{array}{l}1.8 \\
2.7\end{array}$ & $\begin{array}{l}1.4 \\
2.0\end{array}$ & $\begin{array}{l}1.4 \\
1.5\end{array}$ & $\begin{array}{l}1.9 \pm 0.4 \\
2.4 \pm 0.6\end{array}$ & $<0.015$ \\
\hline $\begin{array}{l}\text { Baseline } \\
\text { Minimal } \\
\text { PAP }(m m ~ H g)\end{array}$ & $\begin{array}{l}31 \\
25\end{array}$ & $\begin{array}{l}28 \\
25\end{array}$ & $\begin{array}{l}16 \\
18\end{array}$ & $\begin{array}{l}28 \\
23\end{array}$ & $\begin{array}{c}26 \\
\cdots\end{array}$ & $\begin{array}{l}20 \\
11\end{array}$ & $\begin{array}{l}32 \\
30\end{array}$ & $\begin{array}{r}16 \\
7\end{array}$ & $\begin{array}{l}32 \\
29\end{array}$ & $\begin{array}{l}26 \pm 6 \\
21 \pm 8\end{array}$ & $<0.01$ \\
\hline $\begin{array}{l}\text { Baseline } \\
\text { Minimal } \\
\text { SAR (dynes s cm-5) }\end{array}$ & $\begin{array}{l}54 \\
41\end{array}$ & $\begin{array}{l}42 \\
40\end{array}$ & $\begin{array}{l}34 \\
36\end{array}$ & $\begin{array}{l}34 \\
30\end{array}$ & $\begin{array}{c}34 \\
\cdots\end{array}$ & $\begin{array}{l}31 \\
22\end{array}$ & $\begin{array}{l}51 \\
49\end{array}$ & $\begin{array}{l}26 \\
17\end{array}$ & $\begin{array}{l}45 \\
40\end{array}$ & $\begin{array}{l}39 \pm 9 \\
34 \pm 11\end{array}$ & $<0.02$ \\
\hline $\begin{array}{l}\text { Baseline } \\
\text { Minimal } \\
\text { PAR (dynes s } \mathrm{cm}^{-5} \text { ) }\end{array}$ & $\begin{array}{l}\cdots \\
\cdots\end{array}$ & $\begin{array}{l}2,229 \\
2,289\end{array}$ & $\begin{array}{l}1,460 \\
1,280\end{array}$ & $\begin{array}{l}1,786 \\
2,075\end{array}$ & $\begin{array}{r}1,449 \\
\ldots\end{array}$ & $\begin{array}{r}1,446 \\
903\end{array}$ & $\begin{array}{l}2,133 \\
1,413\end{array}$ & $\begin{array}{l}2,802 \\
2,071\end{array}$ & $\begin{array}{l}1,780 \\
1,692\end{array}$ & $\begin{array}{l}1,872 \pm 493 \\
1,674 \pm 502\end{array}$ & $<0.11$ \\
\hline $\begin{array}{l}\text { Baseline } \\
\text { Minimal } \\
\text { RVSWI }\left(\mathrm{gm} / \mathrm{m}^{2}\right)\end{array}$ & $\begin{array}{l}482 \\
208\end{array}$ & $\begin{array}{l}391 \\
246\end{array}$ & $\begin{array}{l}350 \\
320\end{array}$ & $\begin{array}{l}168 \\
125\end{array}$ & $\begin{array}{l}185 \\
\ldots\end{array}$ & $\begin{array}{r}190 \\
82\end{array}$ & $\begin{array}{l}507 \\
201\end{array}$ & $\begin{array}{l}348 \\
209\end{array}$ & $\begin{array}{l}424 \\
327\end{array}$ & $\begin{array}{l}338 \pm 129 \\
215 \pm 85\end{array}$ & $<0.005$ \\
\hline $\begin{array}{c}\text { Baseline } \\
\text { Maximal } \\
\text { RAP (mm Hg) }\end{array}$ & $\begin{array}{l}15 \\
\cdots\end{array}$ & $\begin{array}{l}8 \\
9\end{array}$ & $\begin{array}{l}10 \\
12\end{array}$ & $\begin{array}{l}3 \\
3\end{array}$ & $\begin{array}{r}5 \\
\cdots\end{array}$ & $\begin{array}{l}9 \\
9\end{array}$ & $\begin{array}{r}8 \\
12\end{array}$ & $\begin{array}{l}5 \\
6\end{array}$ & $\begin{array}{l}7 \\
8\end{array}$ & $\begin{array}{l}8 \pm 4 \\
9 \pm 3\end{array}$ & $<0.06$ \\
\hline $\begin{array}{l}\text { Baseline } \\
\text { Minimal }\end{array}$ & $\begin{array}{r}10 \\
\text { NA }\end{array}$ & $\begin{array}{l}16 \\
12 \\
\end{array}$ & $\begin{array}{l}10 \\
10 \\
\end{array}$ & $\begin{array}{l}18 \\
15 \\
\end{array}$ & $\begin{array}{r}12 \\
\ldots \\
\end{array}$ & $\begin{array}{l}6 \\
5\end{array}$ & $\begin{array}{l}18 \\
12 \\
\end{array}$ & $\begin{array}{l}8 \\
4 \\
\end{array}$ & $\begin{array}{l}20 \\
18 \\
\end{array}$ & $\begin{array}{l}13 \pm 5 \\
11 \pm 5 \\
\end{array}$ & $<0.01$ \\
\hline
\end{tabular}

* Patient 5 had ventricular tachycardia after a $1 \mathrm{mg}$ infusion and was excluded from further analysis. ${ }^{\dagger}$ Technically unsatisfactory radionuclide cardiac blood pool scan.

LVEF = left ventricular ejection fraction; LVFP = left ventricular filling pressure; LVSWI = left ventricular stroke work index; NA = not available; $\mathrm{PAP}=$ mean pulmonary arterial pressure; $\mathrm{PAR}=$ pulmonary arteriolar resistance; $\overline{\mathrm{RAP}}=$ mean right atrial pressure; $\mathrm{RVSWI}=$ right ventricular
stroke work index; $\mathrm{SAR}=$ systemic arteriolar resistance. 
Because cardiac glycosides remain less than ideal agents for chronic inotropic therapy of heart failure despite 2 centuries of use, other orally effective inotropic agents are being actively investigated.

Pharmacologic features of prenalterol: The new inotropic agent prenalterol is a derivative of phenol with a chemical structure resembling the catecholamine isoproterenol. The presumed mechanism of action is stimulation of cardiac beta ${ }_{1}$ adrenergic receptors, which appears to be mediated directly since reserpine-treated animals maintain an inotropic response after administration of prenalterol. ${ }^{1}$ It is effective both parenterally and orally and has relatively selective inotropic effects with a smaller effect on heart rate and systemic arterial pressure.

Animal studies hy Carlsson et al. ${ }^{1}$ demonstrated dose-dependent increases in the rate of rise of left ventricular pressure $(\mathrm{dP} / \mathrm{dt})$ after intravenous prenalterol with fewer chronotropic and arterial vasodilating properties than isoproterenol or terbutaline. Oral administration of 5 to $20 \mathrm{mg}$ of prenalterol by Knaus et al. ${ }^{3}$ to normal volunteers resulted in shortened systolic time intervals with significant increases in heart rate and systolic arterial pressure and a transient decrease in diastolic arterial pressure. Sinus arrhythmias increased significantly with no increase in ventricular or supraventricular extrasystoles. The inotropic effects of prenalterol in normal volunteers are blocked by the selective beta $_{1}$ adrenergic blocking agent metoprolol. ${ }^{4}$ Pharmacokinetic data in normal volunteers demonstrated a mean plasma half-life of 2 hours after intravenous administration of prenalterol, ${ }^{4}$ compared with a plasma half-life of 2 minutes for dobutamine. ${ }^{17} \mathrm{Pre}$ nalterol's electrophysiologic properties include shortened atrioventricular nodal conduction time and atrial refractory period. ${ }^{18}$

Clinical hemodynamic effects of prenalterol: Previous clinical investigations in patients with cardiac disease have also demonstrated beneficial hemodynamic effects. Hutton et al. ${ }^{6}$ demonstrated increased left ventricular $\mathrm{dP} / \mathrm{dt}$ after intravenous administration of prenalterol in patients with ischemic heart disease without changes in heart rate or end-diastolic volume. Prenalterol reversed the decreased heart rate, blood pressure and cardiac output and the increased preejection period after adrenergic blockade with metoprolol following acute myocardial infarction. ${ }^{5} \mathrm{~A}$ preliminary study of oral prenalterol in patients with severe heart failure (functional classes III and IV) showed beneficial effects on left ventricular filling pressure, cardiac index, ejection fraction and exercise tolerance. ${ }^{7}$ Hypotension induced by spinal anesthesia has been reversed by prenalterol. ${ }^{19}$ No significant adverse effects have previously been reported after administration of prenalterol.

The possibility that prolonged administration of prenalterol may be associated with a diminished response, a phenomenon noted with other adrenergic stimulants ${ }^{20}$ including dobutamine, ${ }^{21}$ has not been investigated. The hemodynamic effects of prenalterol
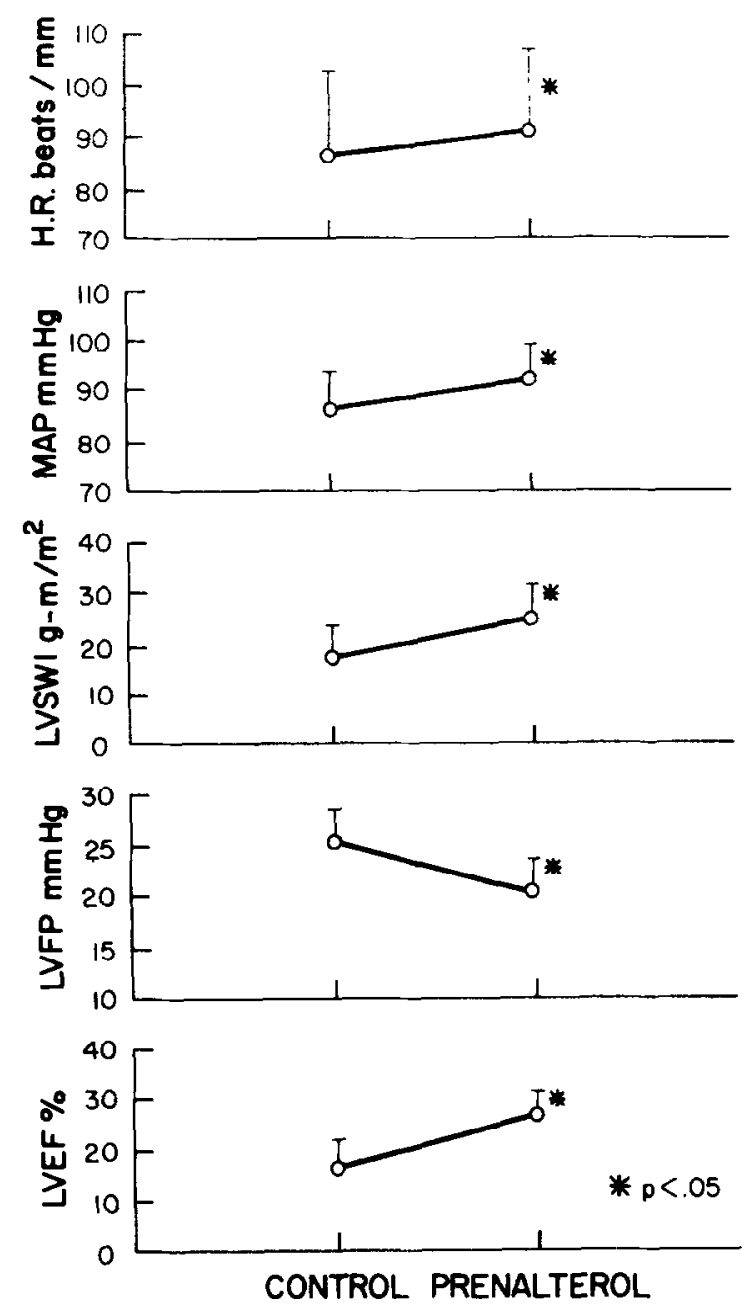

FIGURE 1. Effects of prenalterol on selected hemodynamic variables. Values are expressed as mean \pm standard deviation for control state before drug administration and at peak effect. H.R. = heart rate; LVEF $=$ left ventricular ejection fraction; LVFP = left ventricular filling pressure; LVSWI = left ventricular stroke work index; MAP = mean arterial pressure.

compared with other inotropic agents such as dobutamine and dopamine have not been reported.

The present study demonstrates significant improvement in hemodynamic status after intravenous administration of prenalterol. However, our investigation differs from most previous studies in that only patients with severe low output failure are included. In our study, improved left ventricular performance is demonstrated by statistically significant increases in left ventricular ejection fraction, left ventricular stroke work index and cardiac index. Diminished left ventricular filling pressure may be due to a direct positive inotropic effect resulting in decreased left ventricular end-diastolic volume or due to left ventricular preload reduction from systemic venodilation, or both. The significant reduction in right atrial pressure in our study suggests a systemic venodilating effect. The net hemodynamic effect is a shift in the ventricular function 
curve upward and to the left, as found with other inotropic agents. A statistically significant increase in heart rate after prenalterol indicates a residual chronotropic effect, which may be mediated by stimulation of cardiac beta $_{1}$ adrenergic receptors affecting heart rate. The increase in systolic and mean arterial pressures achieved statistical significance; however, diastolic arterial pressure did not change significantly. These findings are in agreement with those of previous studies.,5 $\mathrm{A}$ decrease in systemic vascular resistance after administration of prenalterol suggests that the increased systolic and mean arterial pressures are related to increased cardiac contractile force rather than arterial vasoconstriction. Significant left ventricular afterload reduction, either by direct beta adrenergic arterial vasodilation or by reflex withdrawal of heightened sympathetic vasoconstrictor tone, is a mechanism by which beta adrenergic stimulants can improve left ventricular performance. ${ }^{22}$

Inotropic effect in the presence of myocardial ischemia: The decrease in abnormally elevated pulmonary vascular resistance after administration of prenalterol in this study is comparable with similar changes noted with dobutamine. ${ }^{22}$ There was considerable variation in the patients' response to prenalterol (Table I). Although increases in heart rate and systemic systolic and mean arterial pressure achieved statistical significance, it is unlikely that the modest nature of these changes would be harmful in most patients. In individual patients, increased ischemia could result from increases in myocardial oxygen consumption (reflected by an increased pressure-rate product) greater than the increase in blood flow to ischemic tissue caused by beta $_{1}$ adrenergic stimulation. ${ }^{23}$ However, no subjective or objective evidence of aggravated ischemia was present in this study or that of Ariniego et al., ${ }^{5}$ who evaluated prenalterol therapy after recent myocardial infarction. Similarly, another selective inotropic agent, dobutamine, was not shown to exert an adverse effect on the size of myocardial infarction in experimental animals ${ }^{24}$ and in patients. ${ }^{25}$

Prenalterol and ventricular arrhythmia: The only adverse effects found in this study were cardiac arrhythmias. Although catheter-induced arrhythmias or arrhythmias related to the underlying disease cannot be excluded, the temporal association of the arrhythmias with drug administration suggests a causal relation. Ventricular ectopic activity has been observed with other inotropic agents including the catecholamine dobutamine ${ }^{26}$ and dopamine, ${ }^{27}$ and these agents may have been equally arrhythmogenic in the patients included in this study. Both patients with ventricular tachycardia after administration of prenalterol in this investigation received chronic oral digoxin therapy (with serum levels in the therapeutic range) for ischemic congestive cardiomyopathy after myocardial infarction, raising the possibility that the combination of prenalterol or other adrenergic inotropic agents and digoxin may induce serious ventricular arrhythmias. Increased sympathetic activity has been associated with digitalis toxicity ${ }^{28}$ and, conversely, beta adrenergic blockade has been found to be of value in the therapy of digitalisinduced cardiac arrhythmias. ${ }^{29}$ Two of our five patients receiving long term oral digoxin therapy did not leave an increase in ventricular ectopic activity. However, the combination of severe ischemic heart failure and previous digoxin therapy appears to warrant particular caution in the administration of prenalterol.

\section{Acknowledgment}

We acknowledge the assistance of Steven Hewlett, the nursing staff of the Cardiac Intensive Care Unit and Jean Clare and Kathleen Worthington of the Nuclear Medicine Division, all of the University of Michigan Medical Center. AB Haessle, a division of $\mathrm{AB}$ Astra, kindly supplied prenalterol and provided grant support for the study.

\section{References}

1. Carisson E, Dahlof C-G, Hedberg A, Persson H, Tangstrand B. Differentiation of cardiac chronotropic and inotroplc effects of $\beta$-adrenoceptor agonists. Naunyn Schmiedebergs Arch Pharmacol 1977;300:101-5.

2. Carlsson E, Ek L, Kopp U, Ablad B. Prenalterol: a new orally active cardiac inotropic compound (abstr). Proceedings VIII World Congress of Cardiology, 1978; Abstract 1266

3. Knaus M, Pfister B, Dubach UC, Imhof PR. Human pharmacology studies with a new, orally active stimulant of cardiac adrenergic beta receptors. Am Heart J 1978;95:602-10.

4. Ronn O, Gratfner $C$, Johnsson G, Jordo L, Lundberg $P$, Wikstrand T. Hemodynamic effects and pharmacokinetics of a new selective beta-1 adrenoceptor agonist, prenalterol, and its interaction with metoprolol in man. Eur J Clin Pharmacol 1979;15:9-13.

5. Arinlego R, Waagstein F, Mombay B, HJalmarson A. Hemodynamic effects of a new $B_{1}$ receptor agonist in acute myocardial infarction. Br Heart J 1979;42:139-46.

6. Hutton I, Murray G, Boyes RN, Rae AP, Hillis WS. Hemodynamic effects of prenalterol in patients with coronary heart disease. $\mathrm{Br}$ Heart J 1980;43:134-7.

7. Waagstein F, Estrada-Yamamoto M, Reyes C, Waltentin I, HJalmarson A. Prenalterol a new beta-agonist in treatment of severe congestive heart failure (abstr). Circulation 1979;60:Suppl II:II141.
8. HJalmarson A, Waagstein F. The advantage of beta ${ }_{1}$-stimulation (prenalterol) and beta ${ }_{1}$-blockade (metoprotol) in the treatment of patients with ischemic heart disease (abstr). Am J Cardiol 1979; 43:415.

9. Reiz S. Hemodynamic effects in hypotension of prenalterol, a

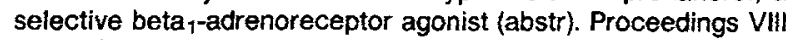
World Congress of Cardiology 1978:Abstract 0892.

10. Criteria Committee of the New York Heart Association. Diseases of the Heart and Great Vessels. Nomenclature and Criteria for Diagnosis. 6th ed. Boston: Little, Brown, 1964:110-4.

11. Beller GA, Smlth TW, Abelmann WH, Haber E, Hood WB. Digitalis intoxication. A prospective clinical study with serum level correlations. N Engl J Med 1971;284:989-97.

12. Doehring $W$. Quinidine-digoxin interaction-pharmacokinetics: underlying mechanism and clinical implications. N Engl J Med 1979;301:400-4.

13. Vogel R, frlschknecht J, Steele P. Short and long term effects of digitalis on resting and post-handgrip hemodynamics in patients with coronary artery disease. Am J Cardiol 1977;40:171-6.

14. Fleg Jh, Gottlieb SH, Laketta EG. Is digitalis really useful in the therapy of chronic congestive heart failure? (abstr). Circulation 1979;60:Suppl II:I1-178.

15. Johnston GD, McDevitt DG. Is maintenance digoxin necessary in patients with sinus rhythm? Lancet 1979;1:567-70. 
16. Hull SM, Mackintosh A. Discontinuation of maintenance digoxin therapy in general practice. Lancet 1977;2:1054-5.

17. Sonnenblick EH, Frishman WH, LeJemtel TH. Dobutamine: a new synthetic cardioactive sympathetic amine. $N$ Engl J Med 1979: 300:17-22.

18. Moore N, Aberg G, Hodess A, Spear J. Some electrophyslologic effects of a new cardiac positive inotropic agent: prenalterol (abstr). VIII World Congress of Cardiology 1978:Abstract 1268.

19. Reiz S, Natu S, Ponten E. Hemodynamic effects of prenalterol, a $\mathrm{B}_{1}$-adrenoceptor agonist, in hypotension induced by high thoracic epidural block in man. Acta Anaesthesiol Scand 1979;23:93-6.

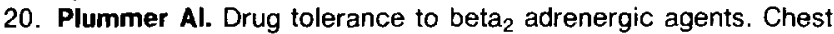
1978;73(Suppl):994-1004.

21. Unverferth DV, Blanford M, Leier CV. Tolerance to dobutamine (abstr). Circulation 1979;60:Suppl II:II-199.

22. Mikulic E, Cohn JN, Franciosa JA. Comparative hemodynamic effects of inotropic and vasodilator drugs in severe heart failure. Circulation 1977;56:528-33.

23. Willerson JT, Hulton I, Watson JT, Platt M. Templeton G. Influence of dobutamine on regional myocardial blood flow and ventricular performance during acute and chronic myocardial ischemia in dogs. Circulation 1976;53:828-33.

24. Tuttle R, Poliack GD, Todd G. Trust R. Dobutamine. Containment of myocardial infarction size by a new inotropic agent (abstr). Circulation 1973;47:Suppl IV:IV-132.

25. Gillespie TA, Ambos HD, Sobel BE, Roberts R. Effects of dobutamine in patients with acute myocardial infarction. Am J Cardiol 1977:39:588-94

26. Jewitt D, Birkhead J, Mitchell A, Dollery C. Clinical cardiovascular pharmacology of dobutamine a selective inotropic catecholamine. Lancet 1974:2:363-7.

27. Goldberg LI. Cardiovascular and renal actions of dopamine: potential clinical applications. Pharmacol Rev 1972;24:1-29.

28. Waxman MB, Chan H, Heimbecker RO. Influence of variations in sympathetic drive on digitalis tolerance (abstr). Clin Res $1971 ; 19: 763$

29. Gibson D, Sowton $E$. The use of beta-adrenergic receptor blocking drugs in dysthythmias. Prog Cardiovase Dis 1969:12:16-39. 